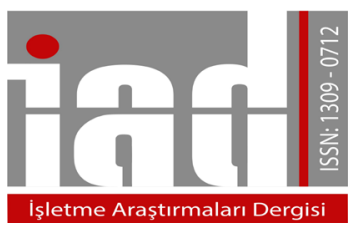

\author{
İşletme Araştırmaları Dergisi \\ Journal of Business Research-Turk \\ 10/4 (2018) 1186-1197
}

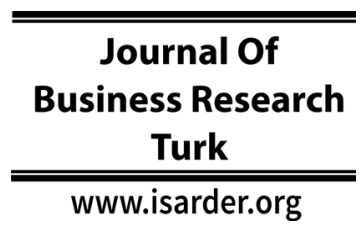

$\underline{\text { Research Article }}$

\title{
The Effect of Dividend Policy on Stock Price: Evidence from An Emerging Country ${ }^{1}$
}

\author{
Harun Dereli \\ Ziraat Yatırım \\ Arastırma Yöneticisi \\ Beyazit- Istanbul / Turkey \\ orcid.org/0000-0001-9994-4607 \\ harde2000@,hotmail.com
}

\author{
Mehmet Sabri Topak \\ Istanbul University, Faculty of Economics \\ Department of Business Administration \\ Beyazit- Istanbul / Turkey \\ orcid.org/0000-0003-2753-9834 \\ msabri@istanbul.edu.tr
}

\begin{abstract}
This study attempts to explore the effect of dividend policy on the stock prices of the companies in Turkey. A balanced panel data set has been formed with 102 companies listed on Borsa Istanbul Industrial Index (XUSIN) for the period 2004-2016. The results of the models used in the study show no statistically significant effect of gross dividend payout ratio, cash dividend payout ratio and their one-year lagged values on stock prices.
\end{abstract}

Keywords: Dividend Policy, Stock Price Return, Borsa Istanbul, Turkey.

Received 10 October 2018; Received in revised from 20 December 2018; Accepted 25 December 2018

\section{Introduction}

With the increase in the institutionalization of business and as a result of the separation of business management and business ownership, the view that the primary objective of a business is to maximize the firm value has become a widely accepted. Therefore, while factors that affect the firm value are gaining more importance, the interest in determining the effect of dividend policies on the firm value has increased. Today, the managers must consider not only the management and the funding of the investments, but also the effect of dividend policy on the firm value.

An investor may obtain two types of gains from investing in stocks: dividend yields and capital gains which arise from the rise in stock value. The investor takes into account both of the factors and behaves according to his position. Considering the expectations of the investors, the business management attempts to establish an optimal

\footnotetext{
${ }^{1}$ This study has been based on the master thesis, "Türkiyede Halka Açık Şirketlerde Kâr Payı Dağıtım Politikalarının Hisse Senedi Değeri Üzerindeki Etkisi: BİST Üzerine Bir Araştırma, 2017, Istanbul University"
}

\section{Suggested Citation:}

Dereli, H., Topak, M.S. (2018). The Effect of Dividend Policy on Stock Price: Evidence from An Emerging Country, Journal of Business Research-Turk, 10 (4), 1186-1197. 
dividend policy that will maximize the firm value and will not have any negative effect on the future investment goals and the cash flow of the firm. For this reason, the way that the investors react to dividend distribution is crucial for the managers.

Various theories have been put forward regarding the correlation between dividend yields and capital gains as well as the effect of dividend distribution on investor preferences. These theories are fundamentally divided into two main views. The first view holds that the dividend distribution is relevant, while the second view holds that it is not.

Miller and Modigliani (1961) were the first to argue in their "Dividend Irrelevance Theory" that dividend policy does not affect the firm value. The Residual Dividend and Clientele Effect theories also suggest that dividend policies do not have an effect on the firm value. On the other hand, as a counterpoint to the dividend irrelevance theory, Bird in Hand theory (Lintner, 1962) constitutes the main theory of dividend relevance, with other theories such as Walter Model (1963), Signalling Theory (Bhattacharya, 1979), Tax Preference Theory (Litzenberger and Ramaswamy, 1979) and the Agency Theory (Rozeff, 1982) supporting it.

Although there have been various studies conducted in the finance literature regarding the validity of both theories, no final result has been reached so far. In this studies that have been conducted, the results differ depending on the country that the business is located in, the sector of the business, the period of activity, the investor profile and the conjuncture. These results indicate that Fischer Black's statement (Black, 1976) "The harder we look at the dividend picture, the more it seems like a puzzle, with pieces that just don't fit together" is still valid.

As a result of the firm value standing out as the ultimate goal of the companies, the study of the factors which affect the firm value still maintains its importance. In this study, we take stock price as an indicator of the firm value while we analyze the relations between firm value and dividend policy in the Turkish Capital Market.

The structure of this paper is as follows: the introduction, the literature review, description of the data and the empirical methodology, findings of the econometric analysis, and the conclusion.

\section{Literature Review}

Many studies have been conducted in the past attempting to explain the relationship between dividend policy and stock prices. There are various studies which support that the dividend earnings have an effect on stock prices.

The first study was introduced by M.J. Gordon in 1959. In his study, Gordon tried to gauge the effects of dividend and retained earnings on stock prices using data from four different sectors in 1951 and 1954 and implied cross-section different regressions. As a result, Gordon found that the dividend earnings have more effect on stock prices than the retained earnings.

The argument that dividend has impact on firm value and is relevant for firm valuation was defended by both John Lintner's "Dividends, Earnings, Leverage, Stock Prices and The Supply of Capital to Corporations" publication in 1962 and Myron J. Gordon's "Optimal Investment and Financing Policy" publication in 1963 independently. According to the Gordon's firm valuation model, the main determinants of value of financing cost of capital are expected infinite series of dividends per share, annual growth of dividends and market price per share of the firm. 
Litzenberger and Ramaswamy (1979) determined a strong positive relationship between pre-tax expected returns and dividend yields of common stocks using the data for the $1936-1977$ period. Evidence was also presented for a clientele effect showing that those stockholders in higher tax brackets choose stocks with low yields, and vice versa.

Nishat and Irfan (2004) attempted to determine the impact of dividend policy on stock price in Pakistan. A sample of 160 listed companies in Karachi Stock Exchange was examined for the 1981- 2000 period. As a result of the study which was conducted based on a cross-sectional regression analysis of the relationship between stock price volatility and dividend policy, both of the dividend policy measures (dividend yield and payout ratio) were found to have significant impact on the stock price volatility.

Pani (2008) investigated the relationship between dividend policy and stock prices for Indian corporations. Companies listed at BSE Index were studied from year 1996 to year 2006. The study employed panel data analysis to examine the relationship between dividend retention ratio and stock price behavior. The results expose that the dividend retention ratio along with the size and the debt-equity ratio play a significant role in explaining variations in stock returns.

Kapoor (2009) examined the relationship between dividend policy and shareholder's value in Indian stock market. The study was conducted to address the issue from the perspective of Indian information technology, fast-moving consumer goods and service sectors respectively. The study discussed the dividend irrelevance theory, agency theory and asymmetric information and concluded that in the Indian scenario, dividend policy has a great effect on the shareholder wealth in the form of share price.

Al Shabibi and Ramesh (2011) studied the possible factors that influence the dividend policy for non-financial companies in UK. Stock price was employed as dependent variable in the study. Industry type, tangibility and corporate governance factors were employed as independent variables. Firm size, debt level, growth and profitability were used as controlled variables. The data they used was a sample of 90 non-financial UK companies and their annual reports. The results showed that the share prices have changed due to the change in dividend policy.

Hussainey, Oscar Mgbame and Chijoke-Mgbame (2011) studied the association between dividend policy and share prices changes for the stock market in UK. They determined share price as a dependent variable while debt level, size, growth rate and earning per share were determined as independent variables. The results showed that the measurements of the dividend policy, dividend yield and dividend payout, caused volatility in stock prices.

Ramadan (2013) studied the effect of dividend policy on the stock price volatility for the 77 industrial companies listed at Amman Stock Exchange. The study covers a twelve-year period starting from 2000 to 2011 . The findings exhibit significant negative effect of the two components of the dividend policy, dividend yield and dividend payout, on the share price volatility.

On the other hand, the dividend irrelevance theory was first put forward by Merton Miller and Franco Modigliani's paper (Dividend Policy, Growth and the Valuation of Shares) in 1961. According to the theory, the dividend policy of a firm is not important for investors and the distribution of dividend has no impact on the firm value. In other words, capital gains and dividend gains are not different things. The only 
factor that affects the firm value is profit generated from the firm's investment policy and future expectation. According to Miller and Modigliani, dividend policy is irrelevant and distribution of dividend is not important for investors.

In line with the dividend irrelevance hypothesis, Black and Scholes (1974) aimed to identify the effect of dividend policy on stock prices via examining the relationship between dividend yield and stock returns. They constructed 25 portfolios composed of New York Stock Exchange listed stocks. In the study capital asset pricing model (CAPM) is used to test the long-run estimate of dividend yield effects. The results exposed that the dividend yield coefficient is not significantly different from zero either. Black and Scholes, therefore, concluded that, "we are unable to show that differences in yield lead to differences in stock prices." In other words, neither high-yield nor lowyield payout policy of companies seemed to influence the stock prices.

Batchelor and Orakçığlu (2003) tested the proposition that stock dividends have no effect on firm value, using a novel GARCH process with event-related intercept terms to capture induced changes in the volatility of stock prices. According to this study, returns rise in advance of stock dividend payments, but this effect becomes statistically insignificant when proper allowance is made for heteroscedasticity. The study documents some irrationality in the responses to cash dividends, with prices rising/ falling after increased/ decreased dividend payments, rather than after the much earlier dividend announcements.

Samad, Shaharudin and $\mathrm{Ha}$ (2007) investigated if there is a significant relationship between a stable dividend policy and firm performance in Malaysian stock market. They used data set of 120 firms from seven different sectors for the period 2001-2005. The study suggested that there was no significant impact of dividend policy on stock market return. CAPM was used to determine stock's respective expected returns. The results showed no significant relationship between dividend policy and abnormal stock returns.

The regression between dividend payout amount and stock prices between 19872006 of 19 IMKB-30 Index companies has been researched by Pekkaya (2006). According to the analysis, there is a statistically significant effect of the dividend payout amount on the stock prices for the 5 companies. As a further result of analysis there is a stronger relation between the amount of retained earnings and stock price than the relation between dividend payout amount and stock prices.

\section{Data and Methodology}

A balanced panel data set of 102 companies from Borsa Istanbul (BIST) Industrial Index (XUSIN) is examined for the period 2004-2016. The length of each period is one year. The reason behind the selection of the year 2004 as the beginning period is the regulations which were implemented in the International/Turkish accounting standards in 2003. The fact that the financial statements of the companies listed in BIST from 2004 became more comparable was the main factor in the selection of period.

The data set is comprised of variables which were calculated from the annual consolidated financial statements of the companies. These financial statements have been obtained from the official website of Public Disclosure Platform (www.kap.gov.tr) and Borsa Istanbul (www.borsaistanbul.com.tr). Macroeconomic indicators used in this set has been taken from the official pages from The Central Bank of the Republic of Turkey(www.tcmb.gov.tr) and the Ministry of Treasury and Finance (www.hazine.gov.tr). Stock prices have been acquired from Finnet data provider. 


\subsection{Definition of Variables}

In order to determine the variables used in this study, previous studies have been taken into consideration. The dependent variable used is the annual change of stock prices of the companies. On the other hand, the independent variables are consisted of two groups: firm-specific and macroeconomic data.

\subsubsection{Dependent Variable}

In order to investigate the effect of dividend policy on firm value, we used the annual change in stock prices as a proxy for firm value changes. Stock prices has been used mostly in literature as a dependent variable as in the studies of Black and Scholes (1974), Samad, Shaharudin and Ha (2007), Pani (2007), Kapoor (2009), Husseiney and Oscar (2011). While calculating the annual return of stocks, the companies' year-end adjusted stock prices are used.

\subsubsection{Independent Variables}

Independent variables are comprised of firm-specific variables which are computed using the data presented in the financial statements, and macroeconomic variables which represent the economic indicators of the Turkish economy. The firmspecific variables are dividend payout ratios, asset turnover ratio, leverage, and size. Gross dividend payout ratio and cash dividend payout ratio are selected as the indicators of dividend policy. Macroeconomic variables which are thought to have an effect on the firm value are interest rate, exchange rate and real GDP growth.

The dependent and independent variables used in this study are presented in Table1.

Table 1: The Variables Used in The Determination of Stock Price

\begin{tabular}{|c|c|c|}
\hline Notation & Variables & Details \\
\hline \multicolumn{3}{|c|}{ Dependent Variable } \\
\hline SPR & Stock Price Return & $\left(\right.$ Stock Price $_{t}-$ Stock Price $\left._{t-1}\right) /$ Stock Price $_{t-1}$ \\
\hline \multicolumn{3}{|c|}{ Independent Variables } \\
\hline \multicolumn{3}{|c|}{ A-Firm-Specific Variables } \\
\hline GDR & Gross Dividend Payout Ratio & (Gross Cash Dividend + Stock Dividend) / Net \\
\hline $\mathrm{CDR}$ & Cash Dividend Payout Ratio & Gross Cash Dividend / Net Income \\
\hline ATO & Asset Turnover Ratio & Net Sales / Average Total Assets \\
\hline LEV & Leverage Ratio & Total Debt / Total Assets \\
\hline SIZE & Total Assets & Log of Total Assets \\
\hline \multicolumn{3}{|c|}{ B-Macroeconomic Variables } \\
\hline GDP & Gross Domestic Product & Annual percentage growth rate of real GDP \\
\hline INT & Interest Rate & Average benchmark interest rate of the period \\
\hline EXC & Exchange Rate & Annual percentage change in exchange rate basket \\
\hline
\end{tabular}

The summary of the statistics of the variables is presented in Table 2 . The average annual stock return of sample companies over the period 2004-2016 is 31\%. During the 
same period, companies' average gross dividend payout ratio and cash dividend payout ratio are $33.5 \%$ and $32.1 \%$ respectively. This result implies that the industrial companies in Turkey prefer cash dividend and almost all dividends are distributed as cash rather than bonus share.

Table 2: Summary Statistics of Variables

\begin{tabular}{|c|c|c|c|c|c|}
\hline Variable & Observation & \multicolumn{1}{l|}{ Mean } & Std.Dev. & Minimum & Maximum \\
\hline SPR & 1.326 & 0.314 & 1.124 & -0.81 & 32.78 \\
\hline GDR & 1.326 & 0.335 & 0.538 & 0.00 & 8.67 \\
\hline CDR & 1.326 & 0.321 & 0.531 & 0.00 & 8.67 \\
\hline ATO & 1.326 & 0.978 & 0.464 & 0.10 & 3.53 \\
\hline LEV & 1.326 & 0.432 & 0.208 & 0.03 & 0.97 \\
\hline SIZE & 1.326 & 5.864 & 1.409 & 2.42 & 10.35 \\
\hline GDP & 1.326 & 0.554 & 0.039 & -0.05 & 0.11 \\
\hline INT & 1.326 & 0.131 & 0.053 & 0.07 & 0.25 \\
\hline EXC & 1.326 & 0.073 & 0.125 & -0.12 & 0.27 \\
\hline
\end{tabular}

\subsection{Empirical Methodology}

This paper attempts to test the impact of dividend policies on the stock value of the listed companies in Turkey by using panel data analysis. Four different models have been used where the annual stock return is taken as the dependent variable. All the independent variables shown in Table 1, except dividend payout ratios which are considered as the indicator of dividend policies, are the same in all models.

Using gross dividend payout ratio and cash dividend payout ratio variables in the same model causes multicollinearity problem. To avoid this problem, two different models have been formed by using these ratios as independent variables. In addition to that, since companies generally distribute the dividends from the previous year's earnings (it is a higher possibility that the distributed dividend has an effect on the firm's current value rather than on its value during the previous year), two more separate models which include one-year lagged value of both gross dividend payout ratio and cash dividend payout ratio were formed.

Gross dividend payout ratio is presented in the model 1 and its one-year lagged value is presented in the model 2 as indicators of dividend policy.

$$
\begin{aligned}
\mathrm{SPR}_{\text {it }}=\beta_{10}+ & \beta_{11} \mathrm{GDR}_{\text {it }}+\beta_{12} \mathrm{ATO}_{\text {it }}+\beta_{13} \mathrm{LEV}_{\text {it }}+\beta_{14} \mathrm{SIZE}_{\mathrm{it}}+\beta_{15} \mathrm{GDP}_{\mathrm{it}} \\
& +\beta_{16} \mathrm{INT}_{\mathrm{it}}+\beta_{17} \mathrm{EXC}_{\mathrm{it}}+\varepsilon_{1, \mathrm{it}} \\
\mathrm{SPR}_{\mathrm{it}}=\beta_{20}+ & \beta_{21} \mathrm{GDR}_{\mathrm{it}-1}+\beta_{22} \mathrm{ATO}_{\mathrm{it}}+\beta_{23} \mathrm{LEV}_{\mathrm{it}}+\beta_{24} \mathrm{SIZE}_{\mathrm{it}}+\beta_{25} \mathrm{GDP}_{\mathrm{it}} \\
& +\beta_{26} \mathrm{INT}_{\mathrm{it}}+\beta_{27} \mathrm{EXC}_{\mathrm{it}}+\varepsilon_{2, \mathrm{it}}
\end{aligned}
$$

On the other hand, cash dividend payout ratio is presented in the model 3 and its one-year lagged value is presented in the model 4 as indicators of dividend policy. 


$$
\begin{aligned}
\mathrm{SPR}_{\text {it }}=\beta_{30}+ & \beta_{31} \mathrm{CDR}_{\text {it }}+\beta_{32} \mathrm{ATO}_{\text {it }}+\beta_{33} \mathrm{LEV}_{\text {it }}+\beta_{34} \mathrm{SIZE}_{\mathrm{it}}+\beta_{35} \mathrm{GDP}_{\mathrm{it}} \\
& +\beta_{36} \mathrm{INT}_{\mathrm{it}}+\beta_{37} \mathrm{EXC}_{\mathrm{it}}+\varepsilon_{3, \mathrm{it}} \\
\mathrm{SPR}_{\mathrm{it}}=\beta_{40}+ & \beta_{41} \mathrm{CDR}_{\mathrm{it}-1}+\beta_{42} \mathrm{ATO}_{\mathrm{it}}+\beta_{43} \mathrm{LEV}_{\mathrm{it}}+\beta_{44} \mathrm{SIZE}_{\mathrm{it}}+\beta_{45} \mathrm{GDP}_{\mathrm{it}} \\
& +\beta_{46} \mathrm{INT}_{\mathrm{it}}+\beta_{47} \mathrm{EXC}_{\mathrm{it}}+\varepsilon_{4, \mathrm{it}}
\end{aligned}
$$

In order to determine the most appropriate panel data model, various tests have been carried out. For this purpose, in all models, LR test was used for individual and/or

\begin{tabular}{|c|c|c|c|}
\hline \multicolumn{4}{|c|}{ Segment A: LR Test: Individual and time effects $\left(H_{0}: \sigma_{\mu_{i}}=\sigma_{\lambda_{t}}=0\right)$} \\
\hline Dependent Variable & Models & Test Statistics & P-value \\
\hline SPR & Model 1 & 16.93 & 0.002 \\
\hline SPR & Model 2 & 18.46 & 0.001 \\
\hline SPR & Model 3 & 17.13 & 0.002 \\
\hline SPR & Model 4 & 18.32 & 0.001 \\
\hline \multicolumn{4}{|c|}{ Segment B: F Test: Individual effects $\left(\mathrm{H}_{0}: \mu_{i}=0\right)$} \\
\hline Dependent Variable & Models & Test Statistics & P-value \\
\hline SPR & Model 1 & 0.79 & 0.9377 \\
\hline SPR & Model 2 & 0.8 & 0.9271 \\
\hline SPR & Model 3 & 0.79 & 0.9376 \\
\hline SPR & Model 4 & 0.8 & 0.9251 \\
\hline \multicolumn{4}{|c|}{ Segment C: LR Test: Time effects $\left(\mathrm{H}_{0}: \sigma_{\lambda_{1}}=0\right)$} \\
\hline Dependent Variable & Models & Test Statistics & P-value \\
\hline SPR & Model 1 & 48.27 & 0.00 \\
\hline SPR & Model 2 & 48.28 & 0.00 \\
\hline SPR & Model 3 & 48.35 & 0.00 \\
\hline SPR & Model 4 & 48.13 & 0.00 \\
\hline
\end{tabular}
time effects; F test for individual effects and test for time effects have been applied for all models. The results of these tests are presented in Table 3.

Table3: Comparing the Models: Tests and Results

According to the results of LR test presented in the segment A of the Table 3, null hypothesis is rejected. Hence, all models will have at least one of the individual and/ or the time effects. According to the results of $F$ test presented in the segment $B$ of the Table 3, main hypothesis for all models which claims that individual effect is equal to zero has not been rejected. Hence, there is no individual effect for all the models. 
Additionally, the results of LR test presented in the segment $C$ of the Table 3 show that main hypothesis which claims that standard deviation of time effects is equal to zero in all models has been rejected. Therefore, all models have time effects. As a result, dummy variables representing time effect for each year have been added to the models.

Deviations from the main assumptions should be tested in panel data models. In view of this fact, the models formed should be tested for autocorrelation and heteroscedasticity. In the case of any deviations detected, robust estimators should be used in estimating the models (Tatoğlu, 2012, p.242)). The test results of the deviations from the assumptions are presented in Table 4 and Table 5.

Table 4:Results of Breusch-Pagan/Cook-Weisberg Test

\begin{tabular}{|c|c|c|}
\hline Models & Test Statistics $\left(\chi^{2}\right)$ & P-value \\
\hline Model 1 & 815.86 & 0.000 \\
\hline Model 2 & 819.39 & 0.000 \\
\hline Model 3 & 813.54 & 0.000 \\
\hline Model 4 & 819.64 & 0.000 \\
\hline
\end{tabular}

In Breusch-Pagan/Cook-Weisberg test, the null hypothesis stated that there is no heteroscedasticity. According to the results presented in Table 4, all models have heteroscedasticity problem.

Table 5: Results of Wooldridge Autocorrelation Test

\begin{tabular}{|l|c|c|}
\hline Models & Test statistics & P-value \\
\hline Model 1 & 5.847 & 0.0174 \\
\hline Model 2 & 5.845 & 0.0174 \\
\hline Model 3 & 5.845 & 0.0174 \\
\hline Model 4 & 5.849 & 0.0174 \\
\hline
\end{tabular}

The existence of autocorrelation in the models has been tested by Wooldridge (2010) test. The results of the test presented in Table 5 indicate that the null hypothesis which proposes that there is no autocorrelation in any of the models has been rejected within the $95 \%$ confidence level.

As a result of the tests applied, the existence of autocorrelation and heteroscedasticity has been accepted for all models. Hence, robust estimators of standard errors should be used in the models to avoid heteroscedasticity and autocorrelation. Due to the existence of autocorrelation and heteroscedasticity, the clustered estimator of standard errors, which was developed by Arellano (1987), Froot (1989) and Rogers (1993), has been used for all models in this study.

\subsection{Empirical Findings}

The results of the final models which were formed to test the effect of dividend policy on the stock price using a sample of industrial companies listed on Borsa Istanbul Industrial Index (XUSIN) in Turkey between 2004 and 2016 are presented in Table 6. 
H. Dereli - M.S. Topak 10/4 (2018) 1186-1197

Table 6: The results of regression equations with Arellano, Froot and Rogers standart errors.

\begin{tabular}{|c|c|c|c|c|c|c|c|c|}
\hline $\begin{array}{l}\text { Dependent } \\
\text { Variable : }\end{array}$ & \multicolumn{2}{|c|}{ SPR } & \multicolumn{2}{|c|}{ SPR } & \multicolumn{2}{|c|}{ SPR } & \multicolumn{2}{|r|}{ SPR } \\
\hline $\begin{array}{l}\text { Independent } \\
\text { Variables : }\end{array}$ & \multicolumn{2}{|c|}{ Model 1} & \multicolumn{2}{|c|}{ Model 2} & \multicolumn{2}{|c|}{ Model 3} & \multicolumn{2}{|c|}{ Model 4} \\
\hline $\begin{array}{l}\text { A- Firm- } \\
\text { Specific V. }\end{array}$ & Coeff. & P-value & Coeff. & P-value & Coeff. & P-value & Coeff. & P-value \\
\hline GDR & 0.010 & 0.774 & & & & & & \\
\hline $\mathrm{GDR}_{\mathrm{t}-1}$ & & & 0.010 & 0.722 & & & & \\
\hline CDR & & & & & 0.018 & 0.591 & & \\
\hline $\mathrm{CDR}_{\mathrm{t}-1}$ & & & & & & & 0.007 & 0.825 \\
\hline ATO & 0.089 & 0.275 & 0.089 & 0.264 & 0.088 & 0.276 & 0.089 & 0.260 \\
\hline LEV & -0.027 & 0.816 & -0.027 & 0.830 & -0.018 & 0.875 & -0.030 & 0.815 \\
\hline SIZE & -0.011 & 0.634 & -0.010 & 0.647 & -0.012 & 0.608 & -0.010 & 0.657 \\
\hline \multicolumn{9}{|c|}{ B- Macroeconomic Variables } \\
\hline GDP & -1.801 & 0.007 & -1.792 & 0.007 & -1.800 & 0.007 & -1.796 & 0.007 \\
\hline INT & -0.454 & 0.627 & -0.049 & 0.598 & -0.458 & 0.624 & -0.498 & 0.594 \\
\hline EXC & -2.436 & 0.000 & -2.434 & 0.000 & -2.437 & 0.000 & -2.434 & 0.000 \\
\hline \multicolumn{9}{|c|}{ C- Time Variables } \\
\hline 2004 & 0.751 & 0.025 & 0.753 & 0.024 & 0.750 & 0.025 & 0.752 & 0.024 \\
\hline 2005 & 0.649 & 0.000 & 0.649 & 0.000 & 0.648 & 0.000 & 0.649 & 0.000 \\
\hline 2006 & -0.011 & 0.880 & -0.010 & 0.889 & -0013 & 0.861 & -0.010 & 0.892 \\
\hline 2007 & 0.270 & 0.002 & 0.269 & 0.002 & 0.269 & 0.002 & 0.269 & 0.002 \\
\hline 2008 & -0.477 & 0.000 & -0.478 & 0.000 & -0.478 & 0.000 & -0.478 & 0.000 \\
\hline 2009 & 1.069 & 0.000 & 1.071 & 0.000 & 1.068 & 0.000 & 1.071 & 0.000 \\
\hline 2010 & 0.741 & 0.000 & -0.740 & 0.000 & 0.740 & 0.000 & 0.741 & 0.000 \\
\hline 2011 & -0.062 & 0.419 & -0.062 & 0.424 & -0.064 & 0.407 & 0.062 & 0.428 \\
\hline 2012 & 0.249 & 0.001 & 0.249 & 0.001 & 0.247 & 0.001 & 0.249 & 0.001 \\
\hline 2013 & -0.079 & 0.285 & -0.080 & 0.289 & -0.080 & 0.278 & -0.079 & 0.293 \\
\hline 2014 & 0.530 & 0.000 & 0.532 & 0.000 & 0.528 & 0.000 & 0.532 & 0.000 \\
\hline 2015 & 0.073 & 0.400 & 0.072 & 0.407 & 0.072 & 0.409 & 0.073 & 0.399 \\
\hline 2016 & 0.169 & 0.045 & 0.168 & 0.049 & 0.167 & 0.046 & 0.169 & 0.048 \\
\hline $\mathrm{F}$ test & 59.64 & 0.00 & 59.92 & 0.00 & 59.48 & 0.000 & 59.85 & 0.000 \\
\hline $\mathrm{R}^{2}$ & \multicolumn{2}{|c|}{0.20} & \multicolumn{2}{|c|}{0.20} & \multicolumn{2}{|c|}{0.20} & \multicolumn{2}{|r|}{0.20} \\
\hline
\end{tabular}


According to the final results presented in Table 6, in all models, the F-test, which produces the general results for models, is significant within the $99 \%$ confidence interval. $20 \%$ of the variation in SPR is actually explained by the variation of independent variables.

In this study, the results indicate that both gross dividend payout ratio and cash dividend payout ratio, which were used as indicators of dividend policy in all the final models, are statistically insignificant. In other words, dividend policies statistically have no impact on stock price return for the 102 industrial companies listed on BIST Industrials Index (XUSIN) between 2004 and 2016. This result is in contrast with the studies of Sealy and Knight (1987), Nishat and Irfan (2004), Samad, Shaharudin and Ha (2007), Pani (2008), Kapoor (2009), Al Shabibi and Ramesh (2011), Hussainey, Oscar Mgbame and Chijoke-Mgbame (2011), and Ramadan (2013). On the other hand, this study provides us similar results as the studies of Black and Scholes (1974), Batchelor and Orakçıoğlu (2003), Pekkaya (2006), Konak and Kendirli (2013).

In addition to that, asset turnover ratio, leverage ratio and size of the firm, which are used as firm-specific variables in this study, have no statistically significant effect on stock price return. In other words, firm-specific variables, including the dividend policies of the companies, are statistically insignificant in explaining the stock price return.

Real growth rates and exchange rates, two of the macroeconomic variables that were used as external variables in explaining stock price return, were found statistically significant within the $95 \%$ confidence interval in all models. Both variables have negative impact on stock price return. On the other hand, the interest rate was found to have no statistically significant effect on stock price return.

Dummy variables, which were used to represent the time effect on the performance of the companies, have statistically significant effect on stock price return in certain years. During the 13 years of time horizon used in this study, the years 2006 , 2011, 2013 and 2015 have no statistically significant effect on stock price return within the $95 \%$ confidence interval while the rest of them were found statistically significant. Also, whereas 2008, the year of economic crisis, has negative impact on stock price return, the effect of the remaining 8 years is positive.

The macroeconomic indicators of Turkey, which can be counted as an emerging market, are not as stable as developed countries, so they have a relatively stronger effect on stock prices. One of the main reasons for the stock price volatility is the lack of effectiveness and the depth in the Turkish capital market. The lack of stability in the capital markets may lead the investors to focus on the macroeconomic indicators and main trend in stock exchange than company specific data. The failure of a systematic dividend policy of Turkish companies, compared to the companies in developed markets, can also be interpreted as a reason for the insignificant relation between the stock prices and dividend policy.

\section{Conclusions}

This study attempts to explore the impact of dividend policy on the stock prices of the industrial companies in Turkey between the years of 2004 and 2016. The data used is a balanced panel data set of 102 companies listed on Borsa Istanbul Industrial Index (XUSIN) for 13-year periods. The results of the 4 final models formed in this study 
showed no statistically significant effect of gross dividend payout ratio and cash dividend payout ratio, the indicators used for the dividend policy, on stock price return. Also, one-year lagged values of these two ratios have no significant impact on stock price return. These results are inconsistent with our previous expectations.

Furthermore, while asset turnover ratio, leverage ratio and size of the firm, which were used as firm-specific variables in the study, have no statistically significant effect on the stock price return, real economic growth rates and exchange rates, two of the macroeconomic variables that were used as external variables in explaining the stock price return, were found to have a statistically significant and negative effect in all the models.

Consequently, the result of this study indicates that Fischer Black's statement "The harder we look at the dividend picture, the more it seems like a puzzle, with pieces that just don't fit together" is still valid for Borsa Istanbul Industrial Companies.

\section{References}

Al Shabibi, B. K., Ramesh, G., (2011). "An empirical study on the determinants of dividend policy in the UK", International Research Journal of Finance and Economics, Vol.80, No.12, 105-120.

Arellano, M., (1987). "Practitioners corner: computing robust standard errors for within-groups estimators", Oxford Bulletin of Economics and Statistics, Vol.49, No.4, 431-434.

Batchelor, R., Orakcioglu, I., (2003). "Event-related GARCH: the impact of stock dividends in Turkey", Applied Financial Economics, Vol.13, No.4, 295-307.

Bhattacharya, S., (1979). "Imperfect information, dividend policy, and the bird in the hand fallacy", Bell Journal of Economics, Vol.10, No.1, 259-270.

Black, F., (1976). "The dividend puzzle", Journal of Portfolio Management, Vol. 2, No.2, 5-8.

Black, F., Scholes, M., (1974). "The effects of dividend yield and dividend policy on common stock prices and returns", Journal of Financial Economics, Vol.1, No.1, $1-22$.

Froot, K.A., (1989). "Consistent covariance matrix estimation with cross-sectional dependence and heteroscedasticity in financial data", Journal of Financial and Quantitative Analysis, Vol.24, No.3, 333-355.

Gordon, M. J., (1959). "Dividends, earnings, and stock prices", The Review of Economics and Statistics, 99-105.

Gordon, M. J., (1963). "Optimal investment and financing policy", The Journal of Finance, Vol.18, No.2, 264-272.

Hussainey, K., Oscar Mgbame, C., Chijoke-Mgbame, A. M., (2011). "Dividend policy and share price volatility: UK evidence", The Journal of Risk Finance, Vol.12, No.1, 57-68.

Kapoor, S., (2009). "Impact of dividend policy on shareholders' value: A study of Indian firms", Jaypee Institute of Information Technology, Doctoral Thesis, 1-39. 
Konak, F., Kenderli, S., (2013). "Kar payı politikalarının hisse senedi fiyatı üzerindeki etkisi: BIST banka endeksi uygulaması", 17. Finans Sempozyumu, 92-99.

Lintner, J., (1962). "Dividends, earnings, leverage, stock prices and the supply of capital to corporations", The Review of Economics and Statistics, Vol.44, No.3, 243-269.

Litzenberger, R. H., Ramaswamy, K., (1979). "The effect of personal taxes and dividends on capital asset prices: theory and empirical evidence", Journal of Financial Economics, Vol.7, No.2, 163-195.

Miller, M.H., Modigliani, F., (1961). "Dividend policy, growth, and the valuation of shares", the Journal of Business, Vol.34, No.4, 411-433.

Nishat, M., Irfan, C.M., (2004). "Dividend policy and stock price volatility in Pakistan", In Pide-19th Annual General Meeting and Conference, 13-15.

Pani, U., (2008). "Dividend policy and stock price behaviour in Indian corporate sector: a panel data approach", Retrieved from Indian Institute of Technology: http://ssrn. com/abstract, 1216171.

Pekkaya, M., (2006). "Kar payı dağıtımının şirket değeri üzerine etkisi: IMKB 30 endeks hisselerine bir analiz", Uluslararası Yönetim İktisat ve İşletme Dergisi, Vol.2, No.4, 183-209.

Ramadan, I. Z., (2013). "Dividend policy and price volatility. Empirical evidence from Jordan", International Journal of Academic Research in Accounting, Finance and Management Sciences, Vol.3, No.2, 15-22.

Rogers, W., (1993). "Regression standard errors in clustered samples", Stata Technical Bulletin, Vol.3. No.13, 19-23.

Rozeff, M.S., (1982). "Growth, beta and agency costs as determinants of dividend payout ratios", Journal of Financial Research, Vol.5, No.3, 249-259.

Samad, F.A., Shaharudin, R.S., Ha S.G., (2007). "Does dividend stability provide a promising stock return? evidence from bursa malaysia", 20th Australasian Finance and Banking Conference, 12-15.

Sealy, N. R., Knight, R. F., (1987). "Dividend policy, share price and return: A study on the Johannesburg Stock Exchange", Investment Analysts Journal, Vol.16, No.29, $33-47$.

Tatoğlu, F. Y., (2012). Panel veri ekonometrisi: stata uygulamalı. Beta Basım Yayın, Istanbul.

Walter, J. E., (1963). "Dividend policy: its influence on the value of the enterprise", The Journal of Finance, Vol.18, No.2, 280-291.

Wooldridge, J. M., (2010). Econometric Analysis of Cross Section and Panel Data. The MIT Press, London. 